\title{
Dendrophthoe pentandra Induced Apoptosis and Cell Cycle Arrest at G1/S in Human Breast Adenocarcinoma Cells, MCF-7 via Up- Regulation of p53
}

\author{
Nik Aina Syazana Nik Zainuddin, Yusmazura Zakaria, Mohd Dasuki Sul'ain* \\ Biomedicine Programme, School of Health Sciences, Universiti Sains Malaysia, 16150 Kota Bharu, Kelantan, Malaysia.
}

\begin{tabular}{l}
\hline ARTICLE INFO \\
\hline Article history: \\
Received on: $24 / 03 / 2018$ \\
Accepted on: $12 / 08 / 2018$ \\
Available online: $30 / 09 / 2018$
\end{tabular}

\section{Key words:}

Dendrophthoe pentandra, apoptosis, MCF-7 cells, flow cytometry analysis.

\begin{abstract}
D. pentandra is a semi-parasitic plant with traditional claim of having antiproliferative and anticancer properties. However, the mechanism underlying anticancer activity of this plant remains unclear. This study aims to evaluate the antiproliferative activity of $D$. pentandra and its mechanism of action in cancer treatment. The extraction of $D$. pentandra was performed using methanol. The antiproliferative activity of $D$. pentandra methanol extract using MTT Assay showed inhibition on MCF-7 cell proliferation with $\mathrm{IC}_{50}$ of $10.65 \pm 0.49 \mu \mathrm{g} / \mathrm{ml}$. Hoechst 33258 nuclear staining displayed chromatin condensation, fragmented nuclei, and formation of apoptotic bodies upon treatment with $\mathrm{IC}_{50}$ of D. pentandra methanol extract. Mechanism of cell death in D. pentandra methanol extract-treated MCF-7 cells were performed by flow cytometric analysis. The analysis confirmed that $D$. pentandra methanol extract-treated MCF-7 arrested cell cycle distribution at the G1/S phase and induced apoptosis using AnnexinV/propidium iodide double staining. The mechanism of action was further confirmed by determination of protein involved in apoptosis pathway; Bcl-2, Bax, and p53. The findings suggested that the increased p53 was followed by an increase of pro-apoptotic Bax and decrease of anti-apoptotic Bcl-2 that led to apoptosis. In conclusion, the anticancer effect of $D$. pentandra methanol extract against MCF-7 cells by induction of apoptotic cell death is a promising approach for breast cancer treatment..
\end{abstract}

\section{INTRODUCTION}

Cancer is a major cause of death worldwide. Each year, about 37, 000 new cancer incidents and 22,000 cancer deaths were reported in developing countries such as Malaysia (Fernandez, 2014). Among Malaysian women, one of three common cancer cases was breast cancer (Dahlui et al., 2011). Hence, there is an urgent need to better control breast cancer case by developing new potent and economical approaches to combat the problem.

Surgery still remains as the most common option for breast cancer treatment with the radiotherapy and chemotherapy (Yaacob et al., 2013; Yip et al., 2014). However, the surgery involves expensive cost and tendency of cancers to invade other tissue by microscopic metastatic (National Breast Cancer Foundation, 2015).

${ }^{*}$ Corresponding Author

Mohd Dasuki Sul'ain (Ph.D.), Biomedicine Programme, School of Health Sciences, Universiti Sains Malaysia, 16150 Kota Bharu, Kelantan, Malaysia.E-mail:_rdasuki@usm.my
Whereas, side effects of chemotherapy and radiation are limited by toxicity effects to healthy tissues in the body (Acton 2013; Yip et al., 2014). Malaysian claimed that usage of herbal medicine is able to improve survivorship regardless of scanty evidence of their effectiveness (Soon et al., 2009; Sooi and Keng, 2013). Hence, it is important to establish and initiate pre-clinical trials especially for the common local traditional herbal medicine.

In this study, Dendrophthoe pentandra (L.) Miq (D. pentandra) or known as mistletoe was chosen based on traditional claim and is easily available. $D$. pentandra is used in to treat diabetes, hypertension, cancer, skin infection and also for postpartum recovery in Indonesia (Ishizu et al., 2002; Artanti et al., 2012). Widowati et al. (2013) reported D. pentandra aqueous extract was potent towards T-47D breast cancer cell lines. Currently, there was no research that explained the mechanism of cell death of $D$. pentandra methanol extract against MCF-7 breast cancer cells, selectively with minimum effect towards normal cells. Thus, 
this present study was performed to determine the potential of $D$. pentandra as an anticancer agent towards breast cancer as well as its antiproliferative property and mechanism of cell death.

\section{MATERIAL AND METHODS}

\section{Plant collection and extraction}

The $D$. pentandra leaves were collected from Pasir Hor, Kelantan, Malaysia and were authenticated by a botanist from School of Biological Sciences, Universiti Sains Malaysia (USM), Penang, Malaysia with voucher specimen number 11289. The leaves were dried in an oven at $50^{\circ} \mathrm{C}$ for 3 days. The extraction was performed as previously described with a slight modification (Zainuddin and Sul'ain, 2015). The D. pentandra was soaked in 100\% methanol (Merck, Germany) with 1:10 ratio and left at room temperature for overnight. The mixture was filtered and the filtrate was concentrated using a rotary evaporator (Heidolph, UK) with settings of the water bath (Memmert, Germany) at $45^{\circ} \mathrm{C}$ for 2 hours. The dark green condensate obtained was dried in the fume hood (ERLA, Malaysia) until a constant weight was obtained. Percentage yield of $D$. pentandra methanol extract was calculated using formula as final weight of $[D$. pentandra methanol extract (g)/initial weight of $D$. pentandra dried powder $(\mathrm{g})] \times 100 \%$.

\section{Antiproliferative activity}

HepG2 (liver cancer cells), U-2 OS (bone cancer cells), MCF-7 (breast cancer cells), MDA-MB-231 (breast cancer cells), HeLa (cervical cancer cells), MDCK (kidney normal cells) and L-929 (connective normal cells) were obtained from ATCC, USA. All cell lines were cultured in Dulbecco's Modified Eagles Medium (DMEM); supplemented with $5 \%$ of foetal bovine serum, $100 \mathrm{IU} /$ $\mathrm{ml}$ of penicillin and $100 \mu \mathrm{g} / \mathrm{ml}$ of streptomycin using $25 \mathrm{~cm}^{2}$ flasks, in $95 \%$ humidified incubator (Sheldon Shell Lab, USA) with $5 \%$ $\mathrm{CO}_{2}$ at $37^{\circ} \mathrm{C}$. All items were purchased from Gibco Laboratories, USA. The antiproliferative activity was carried out using the MTT Assay as reported by Zakaria et al. (2009). Cells were seeded at $5 \times$ $10^{4}$ cells/well in $100 \mu 1$ of medium for overnight. The old medium was discarded before addition of $200 \mu \mathrm{l}$ fresh medium. The $D$. pentandra methanol extract and tamoxifen (Sigma-Aldrich, USA), the positive control were dissolved in dimethyl sulfoxide (DMSO) (Nacalai Tesque, Japan). A range of $0.04 \mu \mathrm{g} / \mathrm{ml}$ to $100 \mu \mathrm{g} / \mathrm{ml}$ of both types of treatment were added to cells. Each well received $2 \mu \mathrm{l}$ of each concentration from the serial dilution. The negative control group was cultured cells in medium with the addition of DMSO. The plates were incubated for 72 hours. Then, $50 \mu 1$ of 2 $\mathrm{mg} / \mathrm{ml}$ MTT solution (Amresco, USA) was added. The plates were incubated for 4 hours. Then, MTT solution was discarded and 200 $\mu 1$ of DMSO was added. Further incubation was performed for 30 minutes using orbital shaker (Heidolph, UK). The absorbance was read on a spectrophotometric microplate reader (Biorad Model $680, \mathrm{USA})$ at $570 \mathrm{~nm}$. Dose-response curves were constructed to determine the $\mathrm{IC}_{50}$ values. A cell line with lowest $\mathrm{IC}_{50}$ value was selected for the rest of the subsequent assays.

\section{Nuclear morphology staining}

The staining was performed as previously described with a slight modification (Zakaria et al., 2009; Zazali et al., 2013). The cells were seeded overnight before the treatment in a sterile Petri dish that consisted of sterile microscope poly-L-sine adhesion slide and medium. The next day, the MCF-7 cells were treated with $\mathrm{IC}_{50}$ of $D$. pentandra methanol extract as well as $\mathrm{IC}_{50}$ of tamoxifen for 24, 48 and 72 hours. Then, the slides were washed with phosphate buffered saline (PBS) and dried at $50^{\circ} \mathrm{C}$. Slides were fixed with cold methanol and then incubated with $30 \mu \mathrm{g} / \mathrm{ml}$ Hoechst 33258 (Sigma-Aldrich, USA) at room temperature for 1 hour in the dark room. Nuclear morphology of each different duration of treatment was examined under a fluorescent microscope (Leica, Germany) at $20 \times$ magnification.

\section{Cell cycle analysis}

The analysis was performed as described by Zakaria et al. (2009) and Zazali et al. (2013). Briefly, the MCF-7 cells were seeded overnight before the treatment in $25 \mathrm{~cm}^{2}$ flasks. The cells were treated with $\mathrm{IC}_{50}$ of $D$. pentandra methanol extract and $\mathrm{IC}_{50}$ of tamoxifen for 24, 48 and 72 hours. At the end of incubation, cells were harvested and collected after centrifuged. All cells were fixed in cold $70 \%$ ethanol and gently vortexed for 1 hour at $20^{\circ} \mathrm{C}$. Pellet of the cell was resuspended in 1\% Triton X-100 (Amresco, USA) in PBS and $100 \mu \mathrm{l}$ of $1 \mathrm{mg} / \mathrm{ml}$ RNase A (Amresco, USA). The mixture was kept at $37^{\circ} \mathrm{C}$ for half an hour. Cells were stained with $100 \mu \mathrm{l}$ of $10 \mu \mathrm{g} / \mathrm{ml}$ propidium iodide (PI) (Sigm-Aldrich, USA) solution in staining buffer. Incubation was allowed at room temperature for 30 minutes. Then, sample tubes were kept in ice. Prior to flow cytometric analysis, $300 \mu \mathrm{l}$ of staining buffer was added and analyzed using flow cytometry (Becton Dickinson FACS CANTO II, USA).

\section{Measurement of apoptosis event}

The quantification was performed as previously reported by Zakaria et al. (2009) and Zazali et al. (2013). The MCF-7 cells were seeded overnight before the treatment in $25 \mathrm{~cm}^{2}$ flasks. The cells were treated with $\mathrm{IC}_{50}$ of $D$. pentandra methanol extract and $\mathrm{IC}_{50}$ of tamoxifen for 24, 48 and 72 hours. At the end of incubation, all cells were harvested and collected after centrifuged. The supernatant was discarded and the cell pellet was rinsed with DMEM. The tubes were spun at $666 \mathrm{x} \times \mathrm{g}$ for 5 minutes. The cell pellet was washed with cold PBS. The tubes were further centrifuged and resuspended in $1 \mathrm{X}$ Assay Buffer. The cell suspension was added with Annexin V FITC/PI (Santa Cruz, USA) and incubated in dark room for 15 minutes. Samples were analyzed immediately within 1 hour using a flow cytometry after addition of $1 \mathrm{X}$ Assay Buffer.

\section{Detection of apoptotic protein}

The analysis was performed as described by Zakaria et al. (2009) and Zazali et al. (2013) with slight modification. The MCF-7 cells were seeded overnight before the treatment in $25 \mathrm{~cm}^{2}$ flasks. The cells were treated with $\mathrm{IC}_{50}$ of $D$. pentandra methanol extract and $\mathrm{IC}_{50}$ of tamoxifen for 24, 48 and 72 hours. At the end of incubation, all cells were harvested, collected and fixed in icecold $70 \%$ ethanol for 1 hour at $20^{\circ} \mathrm{C}$. Then, the cell pellet was washed twice with $1 \mathrm{X}$ PBS and resuspended in blocking buffer with $2 \%$ bovine serum albumin (Amresco, USA) for 10 minutes. The cell pellet was resuspended in PBS to a concentration of $1 \times$ $10^{7}$ cells $/ \mathrm{ml}$ and incubated with antibodies (Santa Cruz, USA) for 30 minutes in the dark at room temperature. The antibodies; Bax- 
phycoerythrin (PE) conjugated, p53-PE conjugated and Bcl-2-PE conjugated were used in this study. The tubes were resuspended in $500 \mu \mathrm{l}$ of $1 \mathrm{X}$ PBS and analyzed by flow cytometry immediately.

\section{Statistical analysis}

Statistical analysis was performed using Graph Pad PRISM Version 6.0 GraphPad Software Inc, California, United
States. Each experiment was conducted in triplicate and data were expressed as mean \pm S.D. Statistical significances of data obtained were calculated and determined using Students' paired t-test or two-way ANOVA with Turkey's multiple comparison tests. The significance level of $0.05(p<0.05)$ was set for null hypothesis rejection.

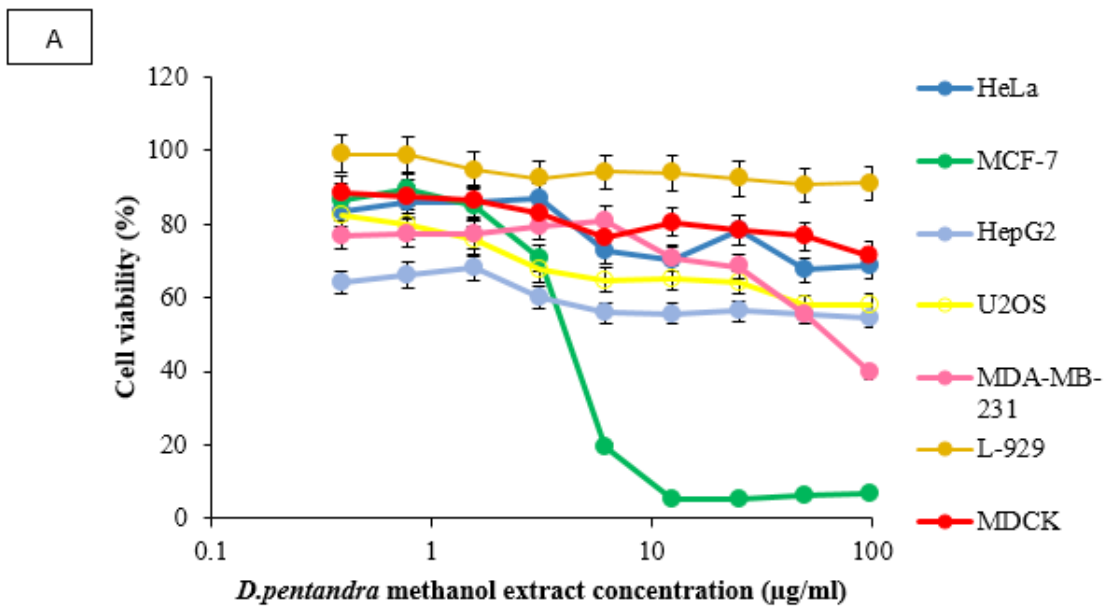

\section{B}

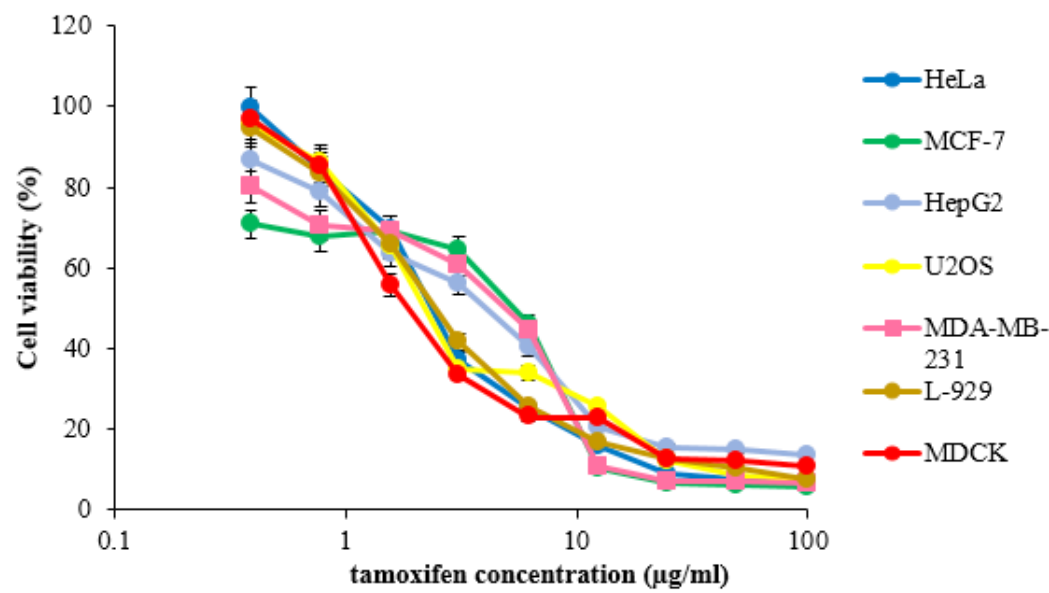

Fig. 1: Antiproliferative activity of $D$. pentandra methanol extract (A) and tamoxifen (B) on HeLa, HepG2, U2OS, MDA-MB-231, MCF-7, MDCK and L-929 cell lines. Each point showed the percentage of viable cells compared to negative control, DMSO. Each point represented as mean \pm S.D, $n=3$.

\section{RESULTS AND DISCUSSION}

\section{Yield of extraction}

Extraction by $100 \%$ methanol showed that $100 \mathrm{~g}$ of $D$. pentandra powder produced $35.8 \mathrm{~g}$ of $D$. pentandra methanol extract with $35.8 \%$ yield. Pattanayak et al. (2011) reported that methanolic extract of Dendrophthoe falcata produced only $12.32 \%$ yield which much lower than the yield in the current study.

\section{Antiproliferative activity}

The effect of $D$. pentandra methanol extract on cell proliferation was obtained from $\mathrm{IC}_{50}$ value, the concentration of drug that caused inhibition of $50 \%$ of cell survival, compared to the drug, in vitro (Matic et al., 2013). According to National Cancer Institute (NCI), a crude extract possessed a good antiproliferative activity if the $\mathrm{IC}_{50}$ value was less than $20 \mu \mathrm{g} / \mathrm{ml}$, following incubation period 48-72 hours (Boik, 2001). The preliminary screening of antiproliferative activity of $D$. pentandra methanol extract was performed to choose the most effective suppression growth of cancerous cells against D. pentandra methanol extract. Among five different types of cancerous cell lines (Figure 1A), D. pentandra methanol extract was most effective towards MCF-7 cells with an $\mathrm{IC}_{50}$ value of $10.65 \pm 0.49 \mu \mathrm{g} / \mathrm{ml}$. There were no remarkable effects on non-malignant cells, L-929 and MDCK cell proliferation throughout all $D$. pentandra methanol extract treatment time. This synchronized with Zazali et al. (2013) report which 
stated that $\mathrm{IC}_{50}$ more than $99 \mu \mathrm{g} / \mathrm{ml}$ on the proliferation of normal cells were considered harmless to the cells. Hence, $D$. pentandra methanol extract was less cytotoxic compared to $D$. pentandra ethyl acetate extract where the $\mathrm{IC}_{50}$ value was reported low as $18.12 \pm 3.46 \mu \mathrm{g} / \mathrm{ml}$ on the proliferation of L-929 cells (Yee et al., 2017). Tamoxifen showed an inhibitory effect where cytotoxic against tested cancerous cell line (Figure 1B) and also cytotoxic against normal cells. In contrast to tamoxifen, D. pentandra methanol extract showed no remarkable effect towards non-malignant cells and cytoselective against MCF-7 cell compared to another type of tested cancerous cells (Zazali et al., 2013; Zainuddin and Sul'ain, 2015). Although D. pentandra methanol extract was less effective compared to tamoxifen in killing MCF-7 cells, it had lower cytotoxicity against the normal cells. Elimination of malignant cells without leaving any adverse effects on normal cells was regarded as apoptosis (Rahman et al., 2013).

\section{Nuclear morphological changes}

Hoechst 33258 dye stained condensed nuclear of apoptotic cells and bound to packed regions of adenine and thymine in double-stranded deoxyribonucleic acid (DNA) to produce enhanced fluorescence (Zakaria et al., 2009; Rahman et $a l ., 2013)$. In this study, there were obvious nuclear morphological changes in MCF-7 cells (Figures 2A, 2D, and 2G) after treatment with $D$. pentandra methanol extract which was indicative of apoptosis. The results obtained showed cell rounding, losing contact with neighboring cells, chromatin condensation and formation of apoptotic bodies were observed throughout the 24 hours to 72 hours of treatment with $D$. pentandra methanol extract. Tamoxifen-treated MCF-7 cells (Figure 2B, 2E, and 2H) displayed similar morphologically apoptotic events and nuclear-fluorescence in all treatment duration. The untreated MCF-7 cells (Figures 2C, $2 \mathrm{~F}$, and 2I) maintained in their shape, remained unstained and had a normal dull blue color nucleus which indicated the cells were not apoptotic cells (Zakaria et al., 2009).
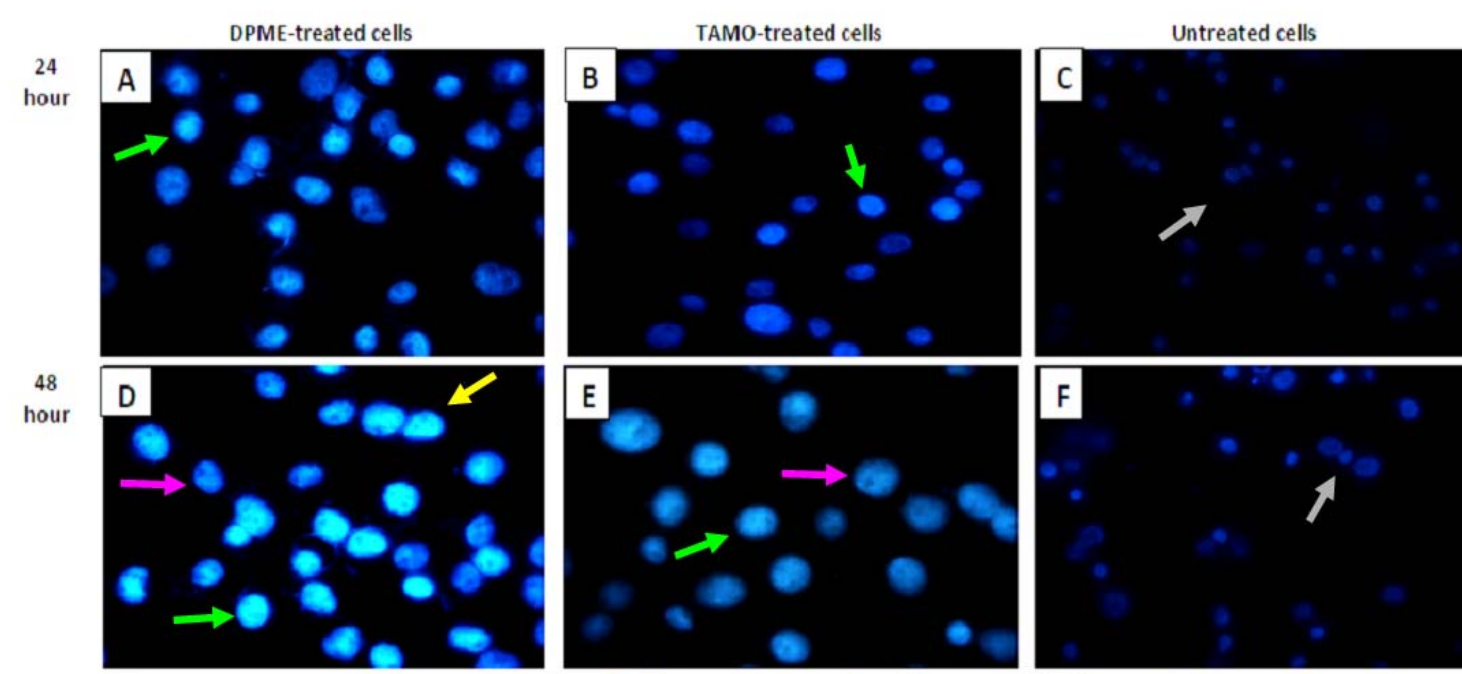

Indication :

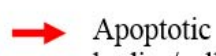

bodies/cell
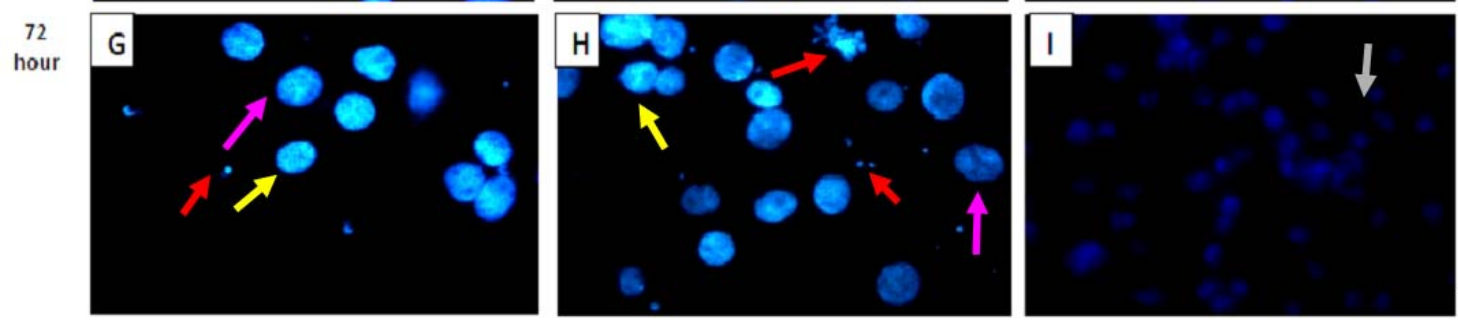

Bright

fluorescence

Cells

rounding up

Chromatin

condensation

Fig. 2: Nuclear staining of MCF-7 cells by Hoechst 33258 dye. Cells were left untreated (C, F and I), treated with D. pentandra methanol extract (A, D, G) and 4.77 $\mu \mathrm{g} / \mathrm{ml}$ with tamoxifen (B, E and $\mathrm{H}$ ) for 24, 48 and 72 hours. Magnification: 20X.

\section{Cell cycle analysis}

Cell cycle arrest had been used as an indicator for the anticancer activity of drugs which led to inhibition of cell growth (Zakaria et al., 2009). In order to determine cell cycle arrest upon treatment with $D$. pentandra methanol extract, PI was used to bind stoichiometrically nucleic acids, leading to fluorescence emission that is proportional to DNA content in cell death. The DNA contents were represented in three distinguishable stages of the cell cycle of G1, S and G2/M phases. The checkpoints for DNA damage were positioned before $\mathrm{S}$ phase, G1/S or after S phase,
G2/M (Zazali et al., 2013). Upon treatment with $D$. pentandra methanol extract (Figure 3 and 4B), DNA content accumulated gradually from $66.29 \pm 1.20 \%$ at 24 hours, $68.74 \pm 0.62 \%$ at 48 hours and $69.08 \pm 0.89 \%$ at 72 hours of G1 phase. After that, S phase took place with a reduced percentage of DNA contents compared to the untreated MCF-7 cells from $25.28 \pm 1.90 \%$ at 24 hours, $28.28 \pm 1.49 \%$ at 48 hours and $28.31 \pm 0.86 \%$ at 72 hours $(p<0.05)$. The DNA contents were significantly reduced during $\mathrm{G} 2 / \mathrm{M}$ phase with $8.45 \pm 1.15 \%$ at 24 hours, $3.05 \pm 0.74 \%$ at 48 hours $(p<0.0001)$ and $2.63 \pm 0.77 \%$ at 72 hours $(p<0.0001)$. At 
this point, the growth of MCF-7 cells was slowed down at a G1/S checkpoint by promoting the G1 arrest. This situation led to the cells being disturbed prior to entering the $\mathrm{S}$ phase to synthesis the DNA. Thus, the growth of MCF-7 cells during the G2 phase of cell division was approaching towards termination. The termination of cell cycle progress in MCF-7 cells might be stimulated by DNA damage that had been triggered by $D$. pentandra methanol extract treatment. As reported by Widowati et al. (2013), the apoptotic cells were obtained by sub-G1 area from cell cycle analysis of $10 \% D$. pentandra aqueous extract induced apoptosis in a T-47D cell line with $24.025 \%$ of apoptotic rate. The data was also in accordance with previous findings by Endharti et al. (2016) that reported $D$. pentandra ethanol extract could prevent colonic epithelial cells proliferation by inhibition of S phase caused the G1 arrest of cell cycle. Treatment with tamoxifen showed a suppression effect on MCF-7 cells by arresting cell cycle progression as the DNA content during G1 phase increased dramatically and the low peak of $\mathrm{G} 2 / \mathrm{M}$ was observed.

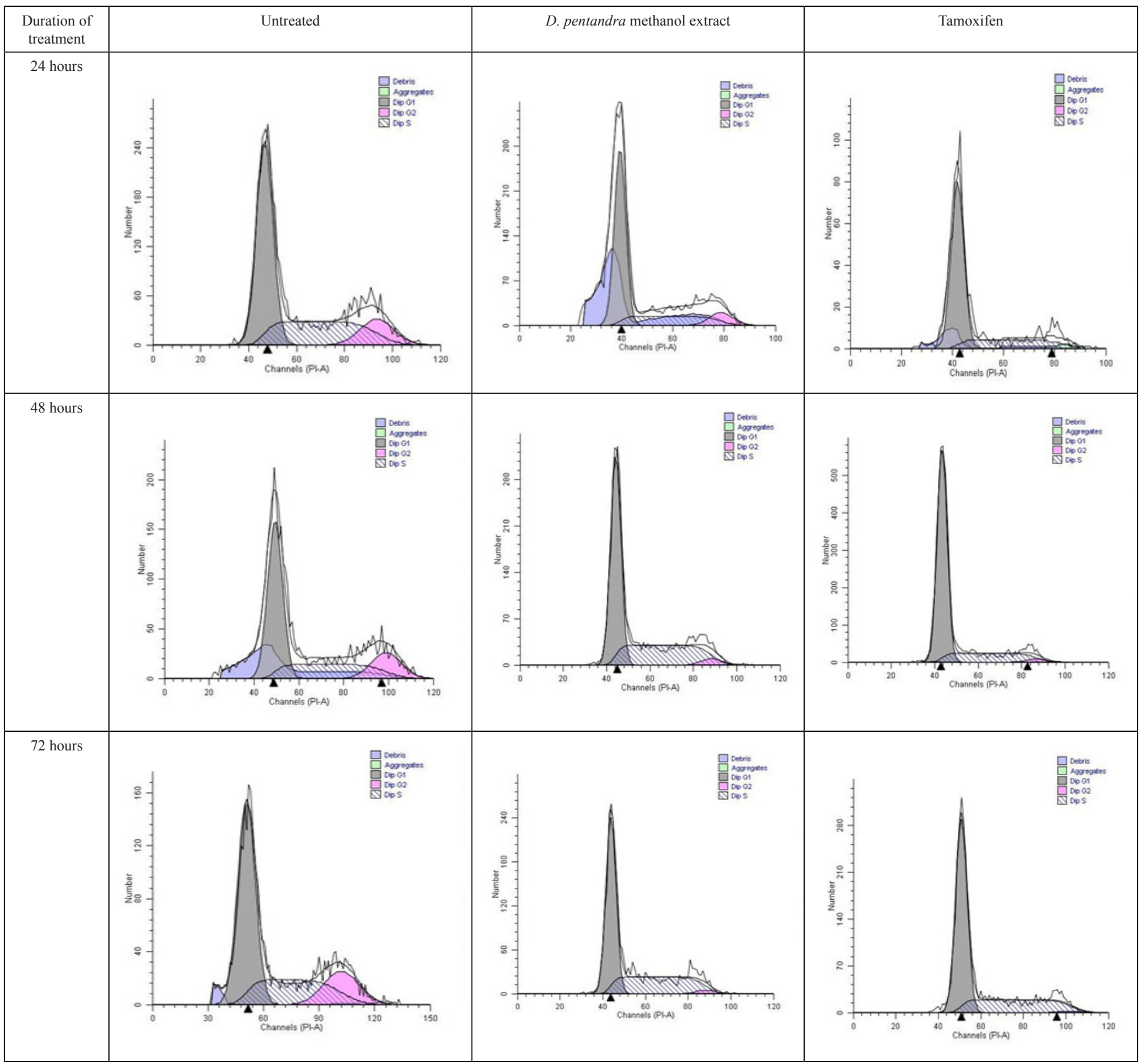

Fig. 3: Histogram profile of cell cycle progression in untreated MCF-7 cells, D. pentandra methanol extract -treated MCF-7 cells and tamoxifen-treated MCF-7 cells for 24 hours, 48 hours and 72 hours. Indication: $\square$ Debris $\square$ G1 $\square$ G2 $\mathbf{N}_{\mathrm{S}}$.

\section{Measurement of apoptosis event}

To further confirm the mechanism of $D$. pentandra methanol extract induced apoptosis in MCF-7, the cells were double - stained with Annexin V-FITC and PI. An early sign of 
apoptosis could be identified by exposure of phosphatidylserine (PS) to the outer layer of cell plasma membrane (Zazali et al., 2013). During early apoptosis, PS were translocated from inner side of cell plasma membrane to outer side, allowing the exposure to be detected by Annexin V, a calcium-dependent phospholipid binding protein that had a high affinity for PS and this could be used for the detection of apoptosis (Arur et al., 2003). Simultaneously, nuclear dye, PI has been probed to examine damage of cell membrane and stained the damaged DNA of cells at their late stages of apoptosis (Zazali et al., 2013; Yaacob et al., 2013). By this condition, apoptotic cells and necrosis cells could be distinguished.
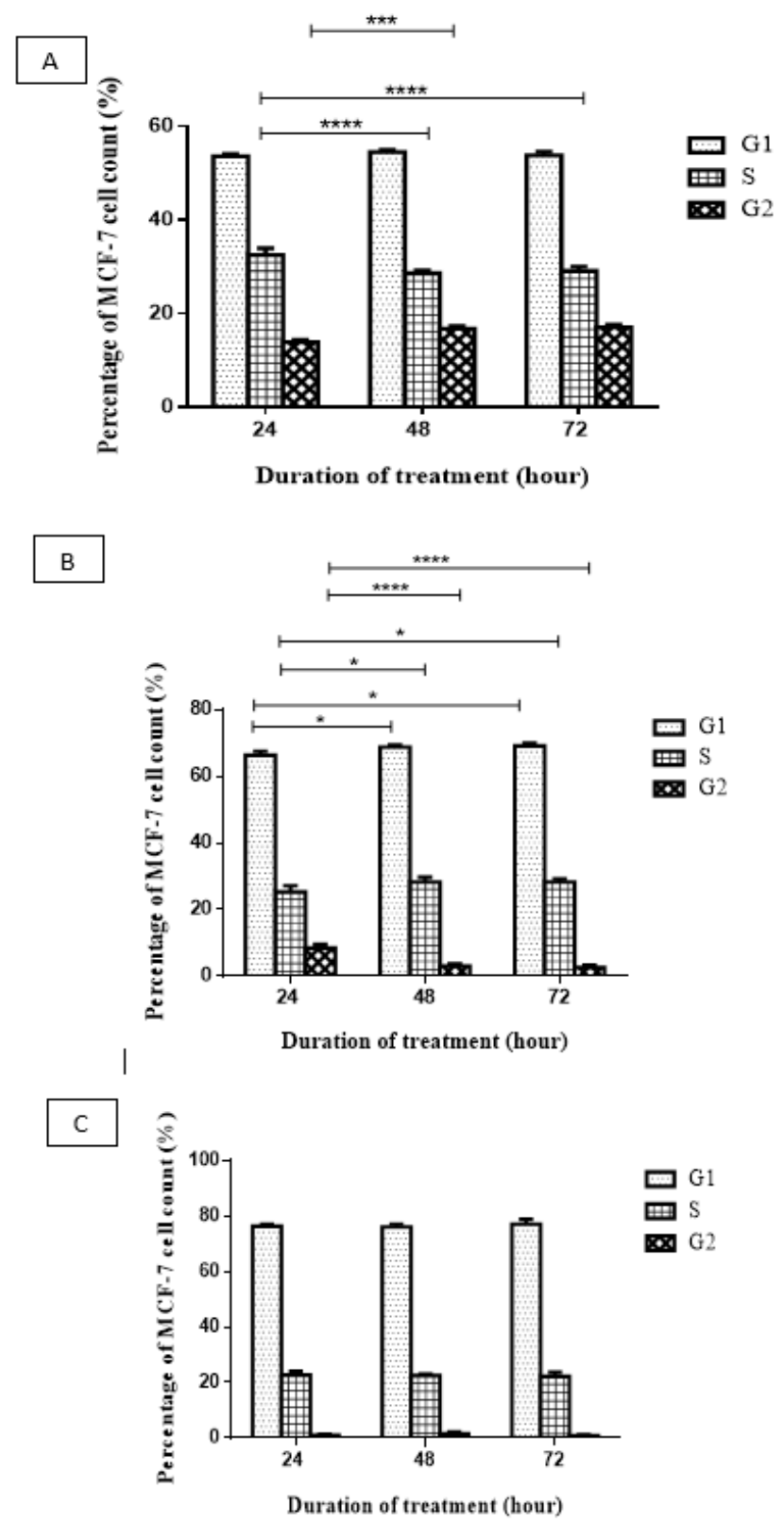

Fig. 4: DNA contents of MCF-7 cells for untreated (A), D. pentandra methanol extract (B) and tamoxifen (C), at each different treatment time. The value of bars represented mean \pm S.D. of three independent experiments, with $* * * * p<$ 0.0001 and $* * * p<0.001$ were taken as extremely significant different, and $* p<$ 0.05 was taken as significantly different with the treatment durations.
In $D$. pentandra methanol extract-treated group (Figure 5 and $6 \mathrm{~B}$ ), the number of viable cells (Q3) was less compared to untreated cells $(p<0.0001)$ from $66.67 \pm 1.45 \%$ to $28.6 \pm 1.21 \%$ and $3.17 \pm 0.35 \%$ during 24,48 and 72 hours of treatment, respectively. This decrement showed that MCF-7 cells were induced to undergo cell death after being treated with $D$. pentandra methanol extract. The percentage of early apoptotic cells (Q4) was initially increased $18.43 \pm 1.46 \%$ to $61.63 \pm 0.75 \%$ and up to $83.63 \pm 1.02 \%$ when incubated for 24,48 and 72 hours $(p<0.0001)$. This proved that apoptosis happened gradually and took place in MCF-7 cells within 48 hours since more than $50 \%$ of cell population undergo early apoptosis event. Wong et al. (2013) also reported similar results in breast cancer cells where Vernonia amygdalina extract induced early apoptosis after 24 hours of treatment in a time-dependent manner, compared to control.

The percentages of cell count detected at late apoptosis quadrant (Q2) for D. pentandra methanol extract were $12.37 \pm$ $1.46 \%, 7.07 \pm 0.75 \%$ and $11.47 \pm 0.78 \%$ throughout 24 hours, 48 hours and 72 hours, respectively. This was significantly different $(p<0.0001)$ when compared throughout treatment time. Some PS of cells still exposed to an outer layer of cell membranes, but consequently, most of the cell membranes were already affected by the treatment. Hence, cell membranes also became permeable towards PI. The percentage of the cell population at necrosis quadrant $(\mathrm{Q} 1)$ remained low at $2.57 \pm 0.12 \%, 2.7 \pm 0.53 \%$, and $1.73 \pm 0.60 \%$ during all incubation periods. The dead cells were necrosis where PS of necrotic cells were not exposed to the outer layer of cells membrane. At this point, the whole cells were already affected and ruptured. This released the DNA and PI could easily bind to necrotic cells. A small population of cells had undergone necrosis and late apoptosis where the cell membranes lost their integrity as shown in the D. pentandra methanol extract-treated tamoxifen-treated group at 72 hours incubation time.

To extend the above findings, the mechanism of apoptosis in $D$. pentandra methanol extract-treated MCF-7 cells was further analyzed by evaluation of apoptotic proteins p53 (Figure 7), Bax (Figure 8) and Bcl-2 (Figure 9). These proteins were among the important models to determine the status of the apoptosis pathway (Jourdain and Martinou, 2009; Zakaria et al., 2009; Zazali et al., 2013). In D. pentandra methanol extracttreated group (Figure 10B), level of p53 protein was increased gradually throughout the treatment period $(p<0.0001)$ where $21.63 \pm 1.33 \%, 66.00 \pm 2.93 \%$ and $75.60 \pm 1.41 \%$ were shown at all treatment period, respectively. By comparing with untreated groups, $\mathrm{p} 53$ expression showed significant difference with $p<$ 0.0001 when treated with $D$. pentandra methanol extract at 72 hours. The expression of Bax proteins was higher as early as 24 hours of post-incubation treatment with $84.43 \pm 2.51 \%$. Slightly increased in Bax expression compared to untreated cells to 90.40 $\pm 1.35 \%$ and $91.60 \pm 1.3 \%$ were observed at 48 hours and 72 hours, respectively. However, the Bcl-2 protein level decrease ( $p$ $<0.0001)$ to $66.4 \pm 1.25 \%, 52.00 \pm 1.61 \%$ and $15.90 \pm 0.80 \%$ throughout 24, 48 and 72 hours, respectively.

Consequently, p53 had influenced the induction of the apoptosis pathway in $D$. pentandra methanol extract. The ability of p53 to express in D. pentandra methanol extract treatment was dependent on 553 protein. In conjunction with the above findings, Bax production was believed to be activated by p53 (Zakaria et 
al., 2009) that highly accumulated in MCF-7 cells. p53 might be responsible for the mechanism of $D$. pentandra methanol extracttreated cells where this condition was proved by the ability of p53 to downregulate $\mathrm{Bcl}-2$ and up-regulate Bax before proceeding to apoptosis pathway (Meenakshii et al., 2000; Abdullah et al., 2010). Acting as a transcription factor, p53 helped to promote apoptosis by transcription of its target genes of Bcl-2 family members. p53 was a widely studied cancer suppressor and its response to diverse forms of cellular stress to mediate a variety of antiproliferative processes has been proven (Abdullah et al., 2010) and has been termed 'the guardian of the genome'. This was due to its pivotal role in managing the integrity of genetic information in response to various genotoxic injuries (Wong et al., 2013). In mammalian cells, there was a notable G1 arrest that seems to be associated by tumor suppressor p53 (Hung et al., 1996). The above finding was in accordance with our earlier data that the $D$. pentandra methanol extract-treated cell stopped cell cycle at G1/S has activated the p53 protein. It was also supported by Endharti et al. (2016) where the G1 arrest of the cell cycle upon treatment with $D$. pentandra ethanol extract was through induction of p53 expression. The efficacy of tamoxifen in this study was also in accordance with Kamal (2014) finding which reported that there were increased p53 expression after 24 hours treatment and remained persistently high after 48 hour treatment towards MCF-7 cells. The apoptotic effect of tamoxifen was associated with some modulation in the expression of $\mathrm{Bcl}-2$ family proteins such as Bax and Bcl-2 (Kallio et al., 2005).

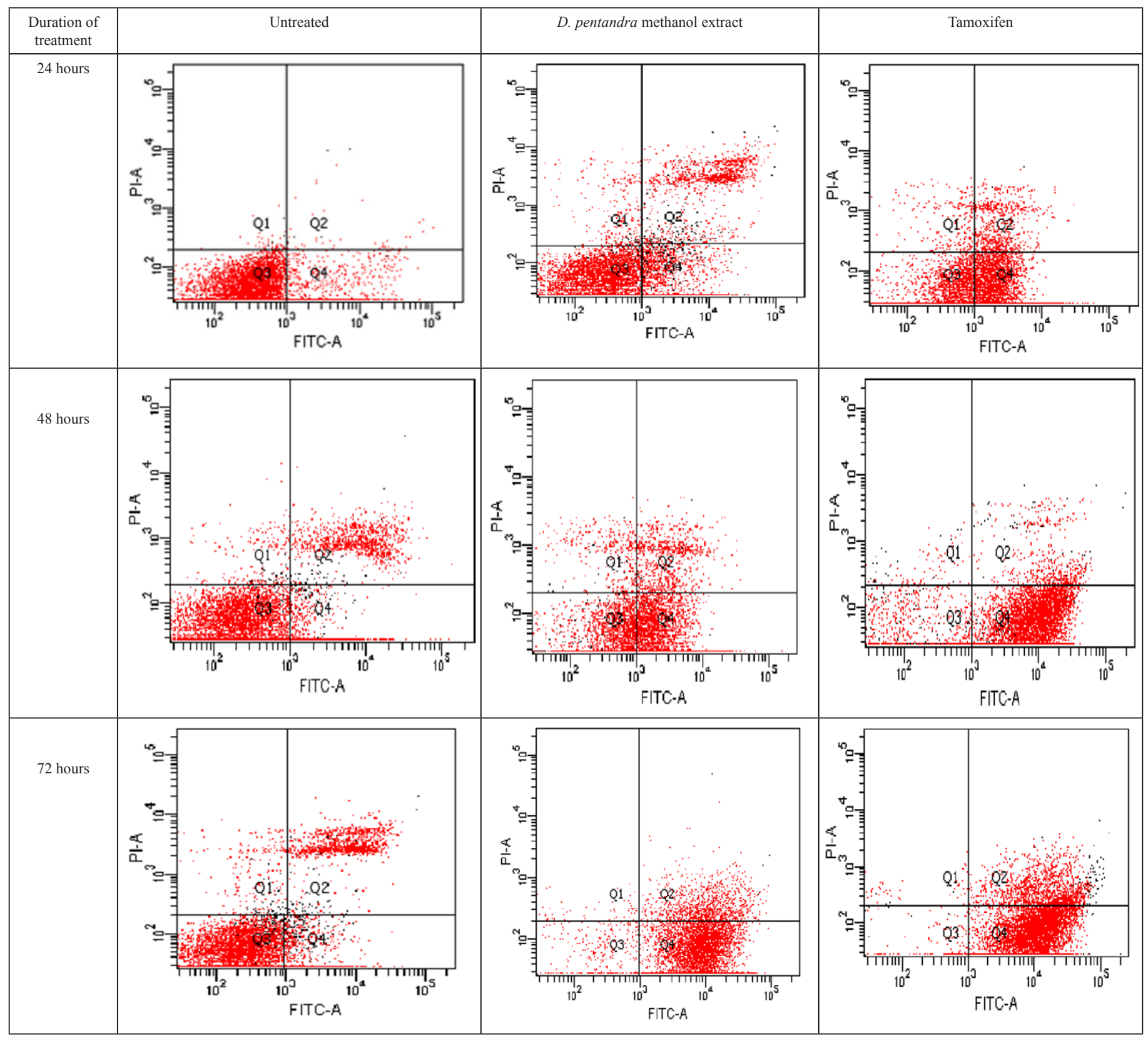

Fig. 5: Scatter plots of MCF-7 cells stained with PI/FITC under four quadrant analysis; viable cells (Q3), early apoptotic cells (Q4), late apoptotic cells (Q2) and necrotic cells (Q1) in untreated MCF-7 cells, D. pentandra methanol extract-treated MCF-7 cells and tamoxifen-treated MCF-7 cells for 24, 48 and 72 hours. 
A
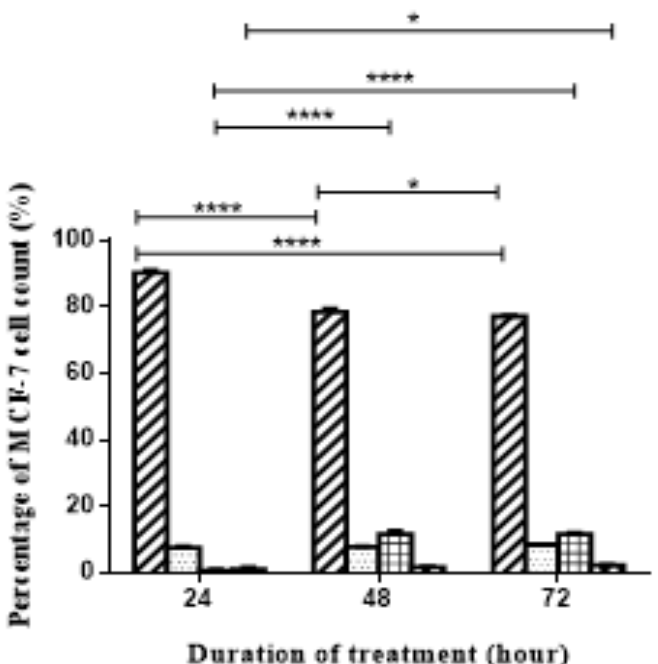

[C viable (Q3)

$\square$ early apoptosis (Q4)

世酯 apoptosis (Q2)

저 necrosis (Q1)

Duration of treatment (hour)

\section{B}

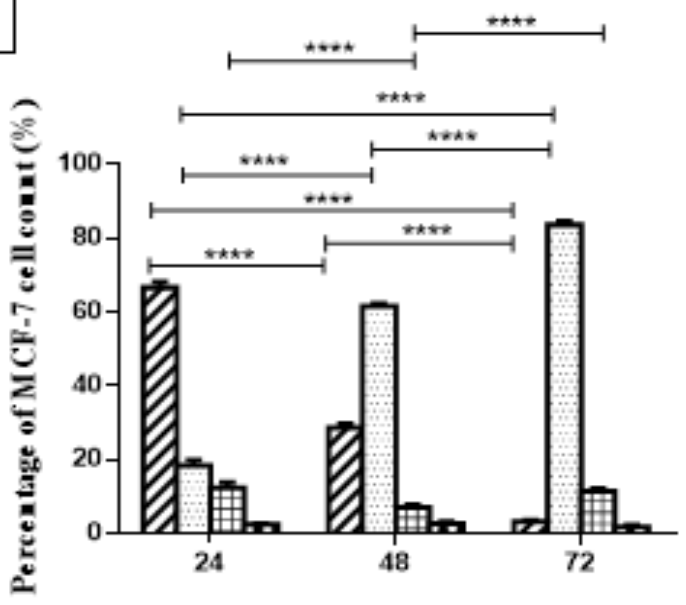

Z7 viable (Q3)

$\square$ early apoptosis (Q4)

\# late apoptosis (Q2)

necrosis (Q1)

Duration of treatment (hour)
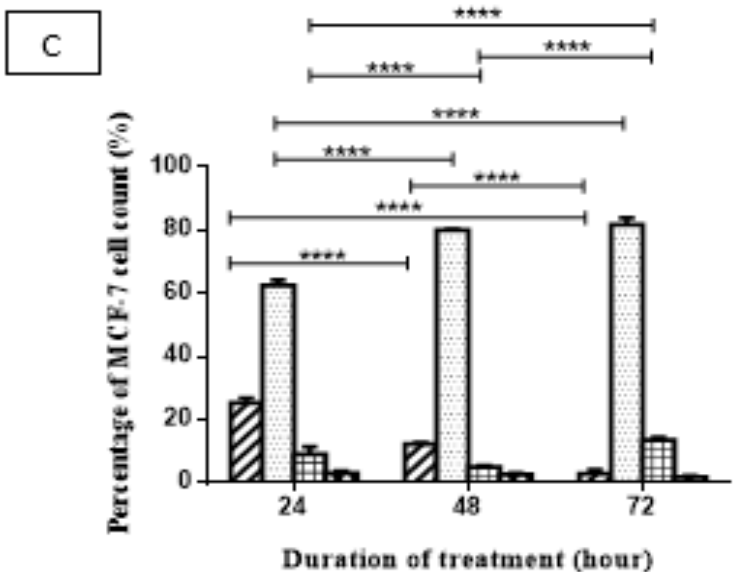

Ea viable (Q3)

$\square$ early apoptosis (Q4)

피 late apoptosis (Q2)

necrosis (Q1)

Fig. 6: Cell count of MCF-7 cells for untreated (A), D. pentandra methanol extract (B) and tamoxifen (C) at each different treatment time. The value of bars represented mean \pm S.D. of three independent experiments, with $* * * * p<0.0001$ was taken as extremely significant different and $* p<0.05$ was taken as significantly different with the treatment durations. 


\section{Detection of apoptotic protein}

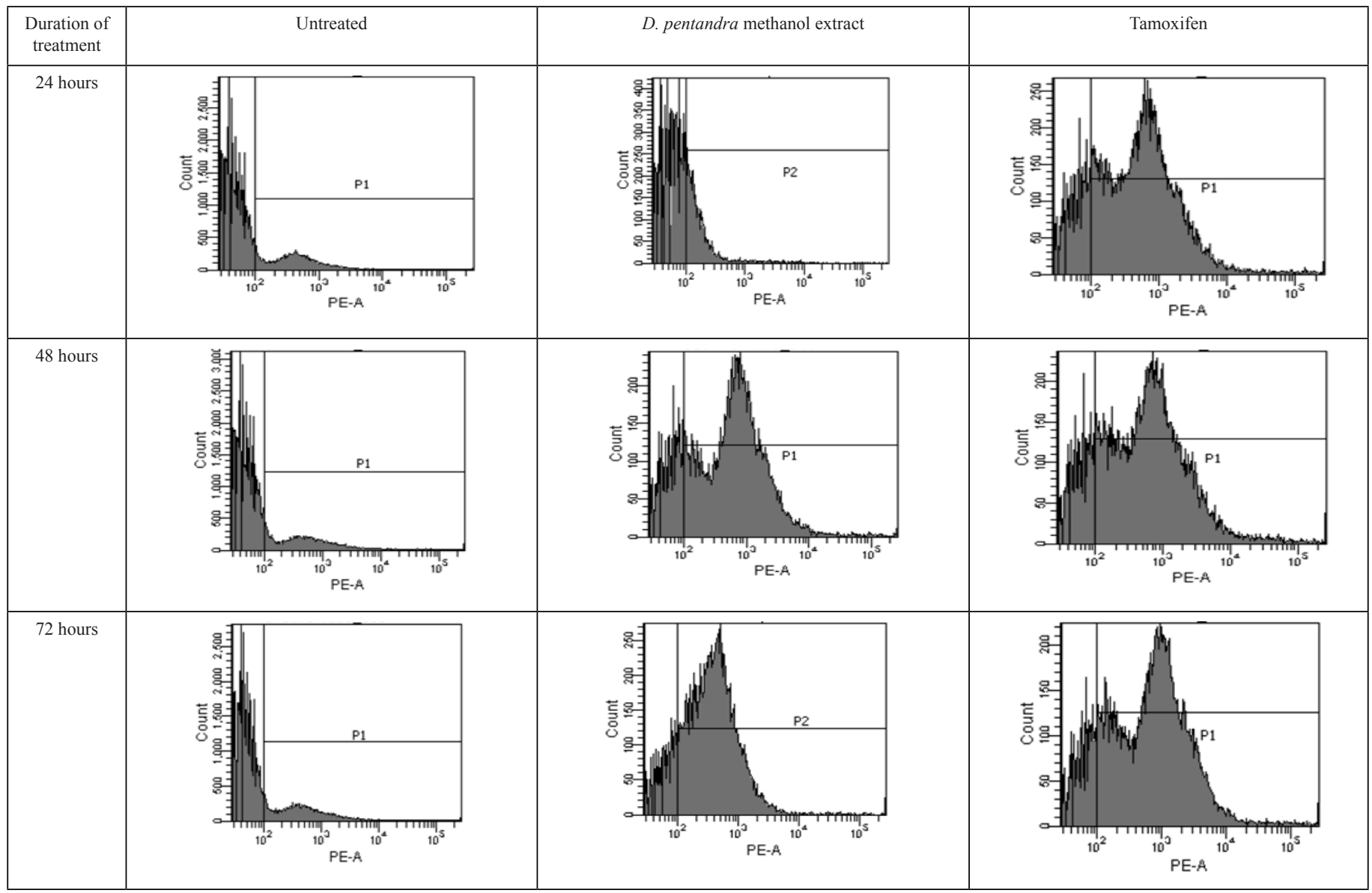

Fig. 7: Histogram profile of p53 proteins expression in untreated MCF-7 cells, D. pentandra methanol extract-treated MCF-cells and tamoxifen-treated MCF-7 cells for 24 hours, 48 hours and 72 hours.

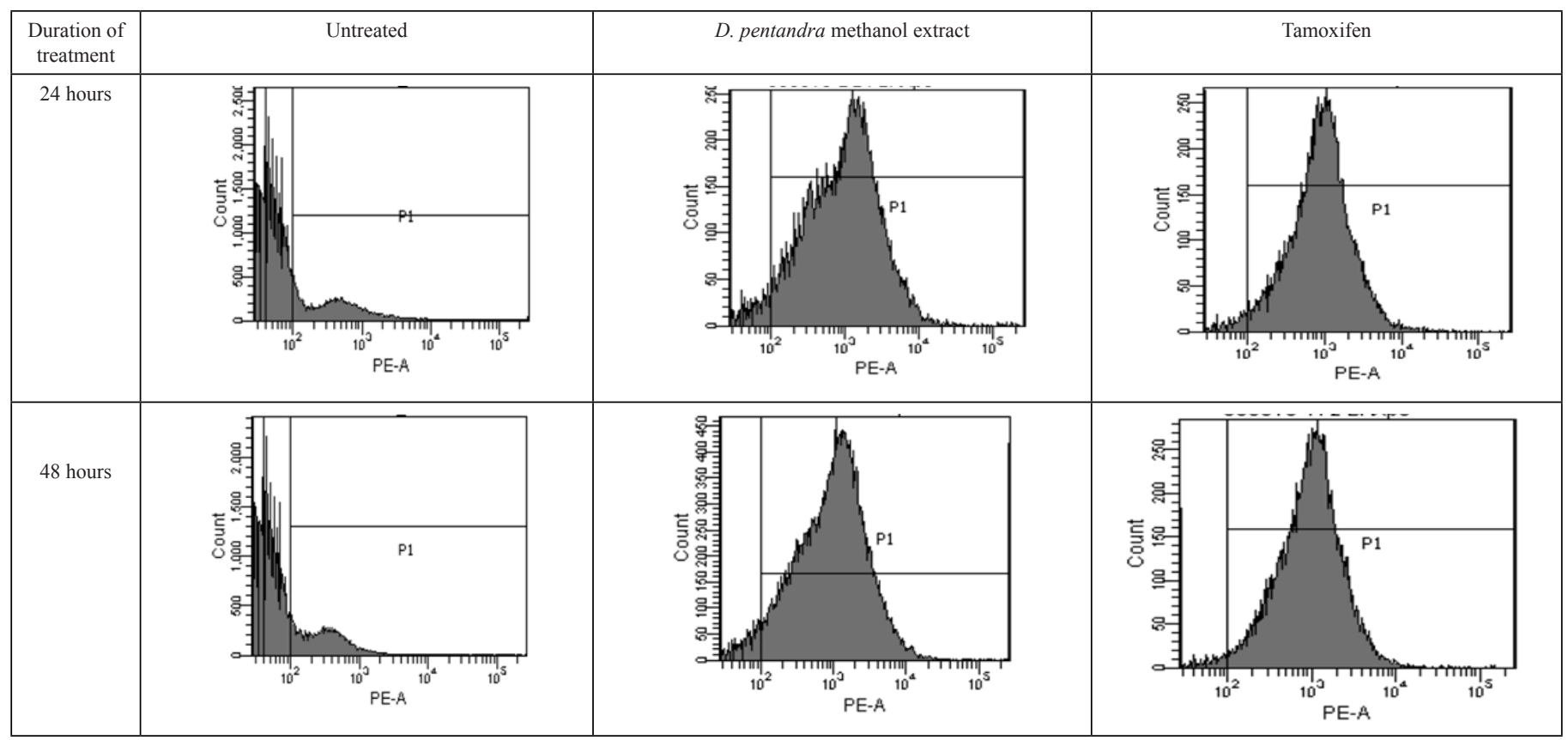



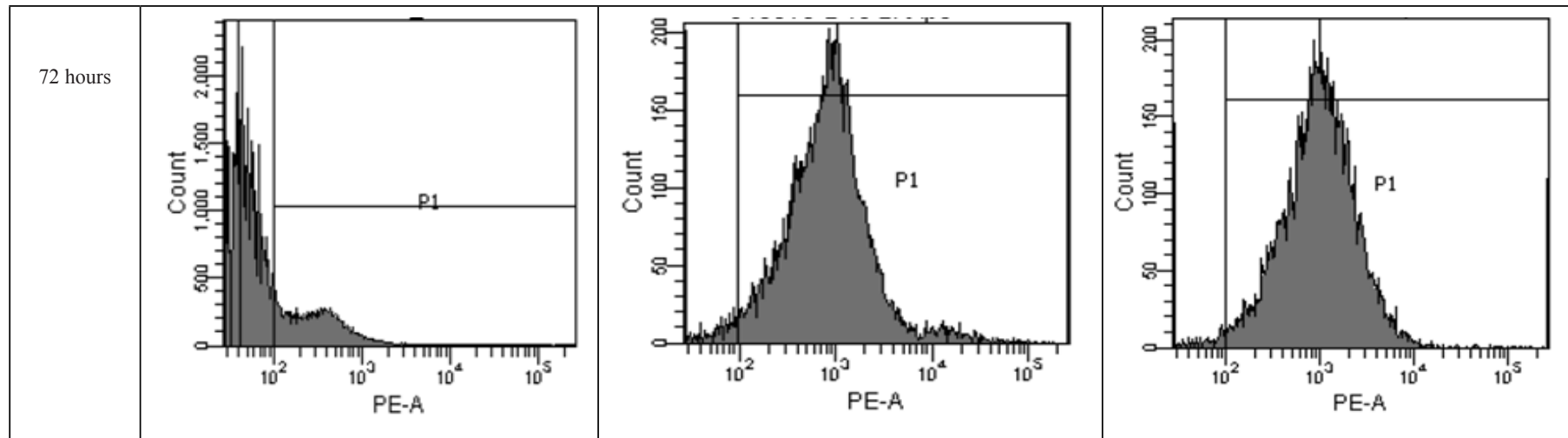

Fig. 8: Histogram profile of Bax proteins expression in untreated MCF-7 cells, D. pentandra methanol extract-treated MCF-cells and tamoxifen-treated MCF-7 cells for 24 hours, 48 hours and 72 hours.

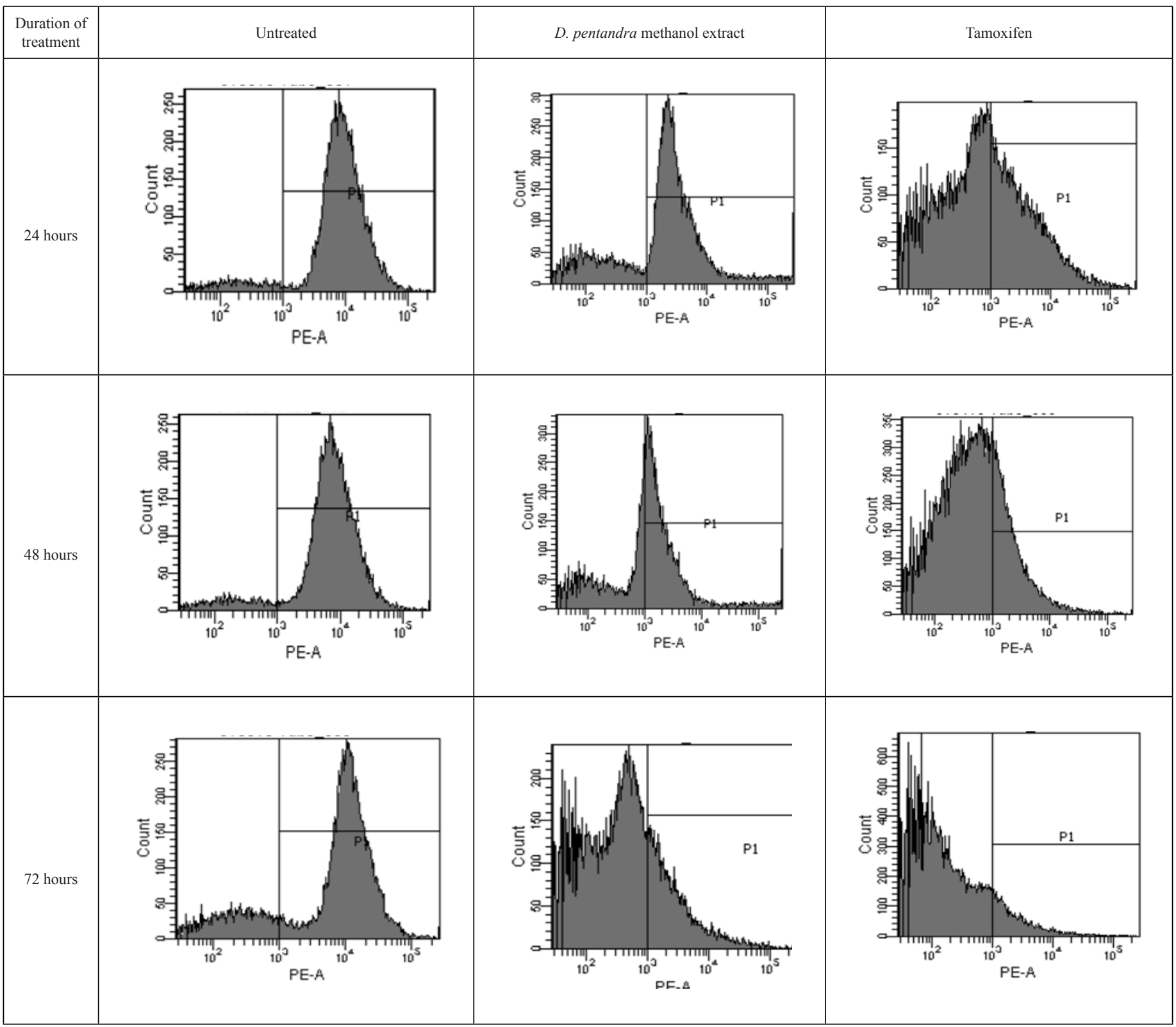

Fig. 9: Histogram profile of Bcl-2 proteins expression in untreated MCF-7 cells, $D$. pentandra methanol extract-treated MCF-cells and tamoxifen-treated MCF-7 cells for 24 hours, 48 hours and 72 hours. 


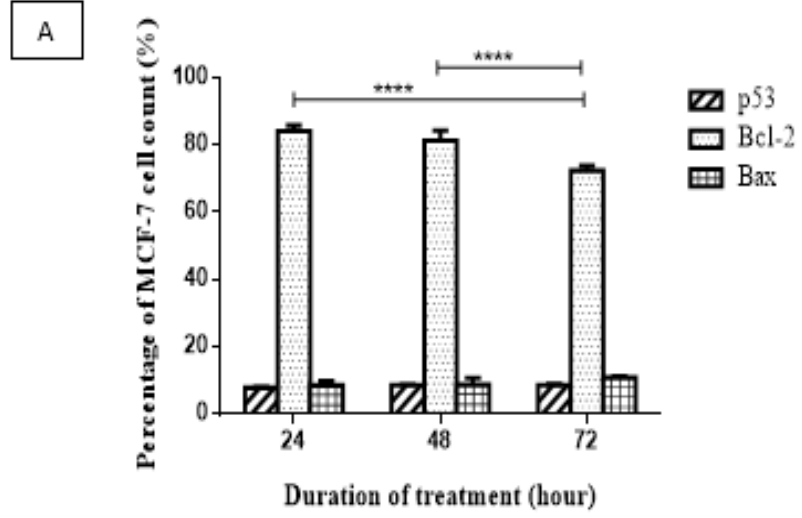

B
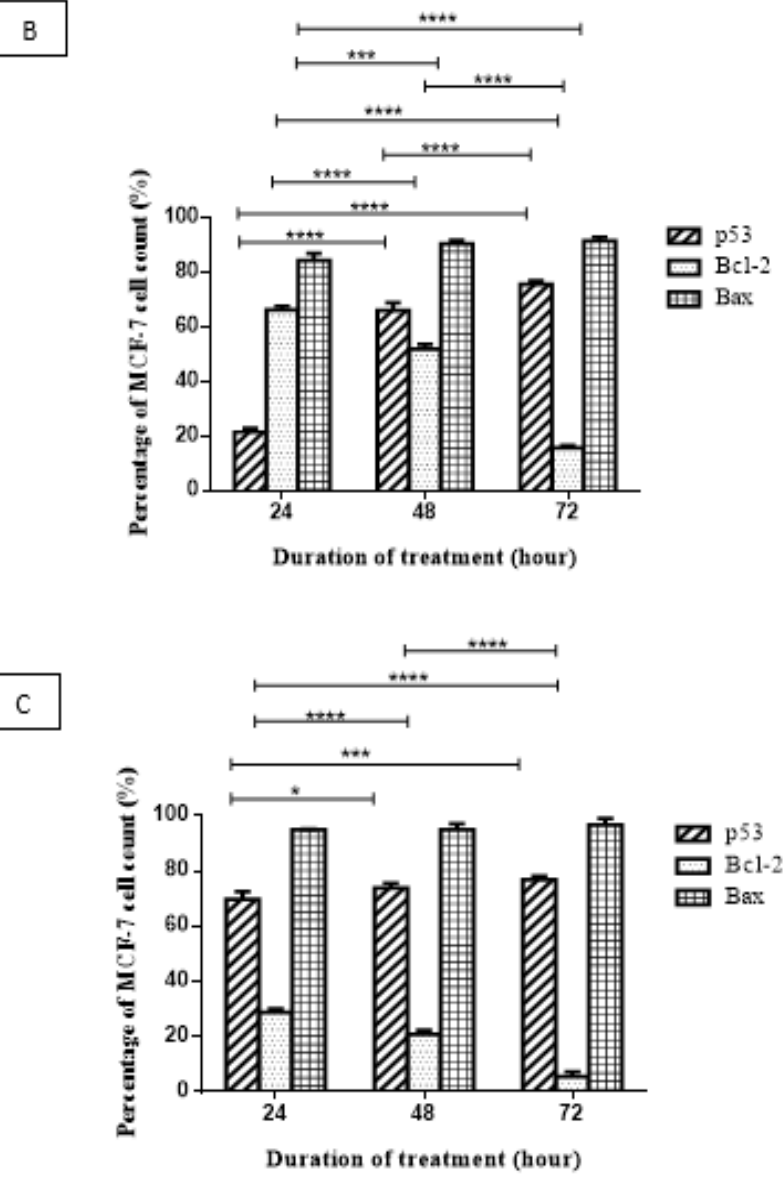

Fig. 10: Cell count of each expression levels of p53, Bcl-2 and Bax for untreated (A), D. pentandra methanol extract (B) and tamoxifen (C) at each different treatment time. The value of bars represented mean \pm S.D. of three independent experiments, with $* * * * p<0.0001$ and $* * * p<0.001$ were taken as extremely significant different and $* p<0.05$ was taken as significantly different with the treatment durations.

\section{CONCLUSION}

D. pentandra methanol extract was selective against MCF-7 breast cancer cells and showed no remarkable negative effect on normal cells. Typical morphologies of apoptosis cell death were displayed throughout all treatment period with $D$. pentandra methanol extract. The growth of MCF-7 cells was arrested at a G1/S checkpoint. This was associated with the help of p53 throughout the apoptosis pathway. In this study, apoptosis was shown as a major cell death mechanism as demonstrated by $D$. pentandra methanol extract which induced early apoptosis in MCF-7 cells. Along with the role of $\mathrm{p} 53$, the apoptosis pathway also was promoted by activation of Bax and inactivation of Bcl-2. The findings from this study proved that $D$. pentandra methanol extract was able to inhibit the proliferation of MCF-7 cells by induction of apoptotic cell death. Thus, $D$. pentandra methanol extract demonstrated potential anticancer activities in MCF-7 cells by apoptosis induction.

\section{CONFLICTS OF INTEREST}

The authors do not have any conflicts of interest regarding the content of the present work.

\section{ACKNOWLEDGMENTS}

This project was financially aided by Fundamental Research Grant Scheme (FRGS), 203/PPSK/6171150, Ministry of Higher Education (MOHE), Malaysia. The research was carried out at the School of Health Sciences (PPSK) and School of Medical Sciences (PPSP), Universiti Sains Malaysia, Kelantan, Malaysia.

\section{REFERENCES}

Abdullah H, Pihie A, Hohmann J, Molnar J. A natural compound from Hydnophytum formicarium induces apoptosis of MCF-7 cells via upregulation of Bax. Cancer Cell Int, 2010; 10:1-6.

Acton Q. 2013. Advances in immunomodulation: Research and Application. Atlanta, Georgia. 22-28.

Artanti N, Firmansyah T, Darmawan A. Bioactivities Evaluation of Indonesian Mistletoes (Dendrophthoe pentandra (L.) Miq.) Leaves Extracts. J App Pharm Sci, 2012; 2:24-27.

Arur S, Uche U, Rezaul K, Fong M, Scranton V, Cowan A, Mohler W, Han D. Annexin I is an endogenous ligand that mediates apoptotic cell engulfment. Dev Cell, 2003; 4:587-598.

Boik J. 2001. Natural Compounds in Cancer Therapy. Minnesota, USA: Oregon Medical Press. 58-63.

Dahlui M, Ramli S, Bulgiba A. Breast cancer prevention and control programs in Malaysia. Asian Pac J Cancer Prev, 2011; 12:16311634.

Endharti AT, Wulandari A, Listyana A, Norahmawati E, Permana S. Dendrophthoe Pentandra (L.) Miq extract effectively inhibits inflammation, proliferation and induces $\mathrm{p} 53$ expression on colitis-associated colon cancer. BMC Complement Altern Med, 2016; 16:1-8.

Fernandez E. More Malaysians to Get Cancer. In New Straits Times, Malaysia, 2014.

Fridman J, Lowe S. Control of apoptosis by p53. Oncogene, 2003; 22:9030-9040.

Hung DT, Jamison TF, Screiber SL. Understanding and controlling the cell cycle with natural products. Curr Biol, 1996; 3:623-639.

Ishizu T, Winarno H, Tsujino E, Morita T, Shibuya H. Indonesian Medicinal Plants. XXIV.1) Stereochemical structure of perseitol K1 complex isolated from the leaves of Scurrula fusca (Loranthaceae). Chem Pharm, 2002; 50:489-492.

Jourdain A, Martinou J. Mitochondrial outer membrane permeabilization and remodelling in apoptosis. Int J Cell Biol, 2009; 41:1884-1889.

Kallio A, Zheng A, Dahllund J, Heiskanen K, Härkönen P. Role of mitochondria in tamoxifen-induced rapid death of MCF-7 breast cancer cells. Apoptosis, 2005; 10:1395-1410.

Kamal NNSNM. Mechanism of SC/D-F9 Anticancer Activity 
and its synergistic effects with tamoxifen in breast cancer cell lines (Dissertation), 2014; Ph.D Universiti Sains Malaysia.

Matic I, Aljancic I, Zizak Z, Vajs V, Jadranin MS, Juranic Z. In vitro antitumor actions of extracts from endemic plant Helichrysum zivojinii. BMC Complement Altern Med, 2013; 13:1-12.

Meenakshii N, Teoh P, Hawariah LA, Hasidah S. Styrylpyrone derivative (SPD) induced apoptosis in ovarian cancer cells correlates with down-regulation of BCL-2 and MAPK but up-regulation of BAX without altering of p53 and c-JUN protein levels. J Trop Med Plants, 2000; 1:1-3.

National Breast Cancer Foundation, Inc (2015) [Online], [Accessed 10 $0^{\text {th }}$ October 2015]. Available from World Wide Web: http:// www.nationalbreastcancer.org/breast-cancer-facts.

Pattanayak S, Mazumder P, Sunita P. Total phenolic content, flavonoid content and in vitro antioxidant activities of Dendrophthoe falcata (L.f.) Ettingsh. Int J PharmTech Res., 2011; 3:1392-1406.

Rahman SNSA, Wahab NA, Malek SNA. In vitro Morphological Assessment of Apoptosis Induced by Antiproliferative Constituents from Rhizomes of Curcuma zedonia. Evid Based Complement Alternat Med, 2013; 257108:1-14.

Sooi L, Keng S. Herbal Medicines: Malaysian Women's Knowledge and Practice. Evid Based Complement Alternat Med, 2013. 438139:1-10.

Soon L, Law S, Mohsin S, Farid C. Use of herbal medicine during pregnancy: a cross sectional survey. Malay J Obstet and Gynecol, 2009; 8:31-35.

Widowati W, Mozef T, Risdian C, Yellianty Y. Anticancer and free radical scavenging potency of Catharanthus roseus, Dendrophthoe pentandra, Piper betle and Curcuma mangga extracts in breast cancer cell lines. Oxid Antioxid Med Sci, 2013; 2:137-142.

Wong F, Woo C, Hsu A, Tan B. The Anti-cancer Activities of
Vernonia amygdalina Extract in Human Breast Cancer Cell Line Are Mediated through Caspase-Dependent and p53-Independent Pathways. PloS ONE, 2013; 8:1-15.

Yaacob N, Nengsih A, Norazmi M. Tualang Honey Promotes Apoptotic Cell Death Induced by Tamoxifen in Breast Cancer Cell Lines. Evid Based Complement Alternat Med, 2013; 989841:1-9.

Yee LS, Fauzi NFM, Najihah NN, Daud NM, Sulain MD. Study of Dendrophthoe Pentandra Ethyl Acetate Extract as Potential Anticancer Candidate on Safety and Toxicity Aspects. J Anal Pharm Res, 2017; 6:160167.

Yip C, Pathy N, Teo S. A Review of Breast Cancer Research in Malaysia. Med J Malaysia, 2014; 69:8-22.

Zainuddin NASN, Sul'ain MD. Antiproliferative Effect of Dendrophthoe pentandra Leaves Extracts towards Human Breast Adenocarcinoma Cells, MCF-7 cells. J Teknol (Sciences \& Engineering.) Special Issue: Propelling Science and Technology through Natural Products, 2015; 7:35-39.

Zakaria Y, Rahmat A, Pihie AL, Abdullah N, Houghton P. Eurycomanone induce apoptosis in HepG2 cells via up-regulation of p53. Cancer Cell Int, 2009; 9:1-21.

Zazali K, Abdullah H, Jamil N. Methanol extract of Oroxylum indicum leaves induces G1/S cell cycle arrest in HeLa cells via p53mediated pathway. Int J Med Plant Res, 2013; 2:225-237.

\section{How to cite this article:}

Zainuddin NASN, Zakaria Y, Sul'ain MD. Dendrophthoe pentandra Induced Apoptosis and Cell Cycle Arrest at G1/S in Human Breast Adenocarcinoma Cells, MCF-7 via UpRegulation of p53. J App Pharm Sci, 2018; 8(09): 130-141. 